it is based on wide observations of facts and long reflection on the elements of the problem, in which I have had the assistance and support of many able geologists, and they are views which cannot wisely be dismissed without careful consideration of the arguments upon which they rest. The theory is not without its difficulties; neither is any other. Geology is not an exact science. There is no infallible court of appeal for the settlement of theo ries. Observers and students of the facts may widely differ for a long time in their conclusions without discredit to either party. I can only ask for freedom of opinion and freedom of utterance.

oberlin, 0 .

G. FREDERICK WRIGHT.

Notice of the Occurrence of Nyctale Richardsoni, Richardson's Owl, in Nebraska.

THE occurrence in this region of Richardson's owl, Nyctale Richardsoni, seems to be entirely established by the recent capture of one in Lincoln. This is a long distance below its soutbern limit, and its appearance is something of a surprise.

However, Professor Lawrence Bruner, who has stuffed and mounted this rare owl, noticed one as a boy, twenty four years ago, near Omaha. Ornithologists at the time questioned the accuracy of his observations, but this specimen confirms the probability of his claim.

The present specimen, which is the first actually taken in the State, was captured on 33d Street, in the city of Lincoln, Dec. 12, and was brought alive to the State Museum. It lived but a short time, however, owing perhaps to injuries, or to the heat. The bird is an adult, in fine plumage.

The unexpected appearance of this inhabitant of Arctic regions seems the more striking from the fact that the weather in Nebraska thus far, barring one snow-storm, has been a mild, protracted autumn rather than winter.

University of Nebraska, Lincoln, Neb., Dec. 14.

\section{Vagueness of Localization in a Child.}

The following are illustrations of the vagueness of the localization of cutaneous sensations in children. The one referred to is 16 months old. The morning after she had been vaccinated, and for a considerable time afterward, she was unable to tell on which arm the sensitive spot was situated, often looking at or touching the wrong one. On one occasion the child sat down with her back close to a grate-fire; as soon as the heat had penetrated the clothing, she began pulling at and striking her chest as though the sensation were there. M. SCRIPTURE.

New Haven, Conn.

\section{Ballistic Galvanometer.}

CAN any of your readers furnish me with complete references on the use of the ballistic galvanometer for measurements of time? E. W. SCRIPTURE.

Yale University, New Haven, Conn.

\section{BOOK-REVIEWS,}

The California Vine Disease. By Newton B. Pierce Bulletin No. 2. Division of Vegetable Pathology, U. S. Dep't. Agric. Washington, 1892. $222 \mathrm{p}, \mathrm{pl}$. 25, charts 2.

Report on the Experiments made in 1891 in the Treatment of Plant Diseases. By B. T. Galloway. Bulletin No. 3. Division of Vegetable Pathology, U. S. Dep't. Agric. Washington, $1892 . \quad 76 \mathrm{p}, \mathrm{pl} .8$.

Grasses of the Pacific Slope, including Alaska and the Adjacent Islands. By Geo. VAseY. Bulletin No. 13. Division of Botany. U. S. Dep't. Agric. Washington, 1892. 50 plates, with descriptions.

THESE three publications which have followed one another rapidly from the Government printing office are of diverse character. The first deals with the results of an investigation extending over two years into the character of an obscure but virulent disease of vines in California; the second records the results of a series of experiments to prevent the ravages of several plantdiseases in the eastern portion of the country; and the third gives descriptions and plates of fifty-two species of grasses found growing on the Pacific coast of our country, including Alaska.

The California vine disease seems to have first appeared in the vicinity of Anaheim, Orange County, in 1885, but it did not attract great attention until the following year, when it caused the death of a large number of vines. From this, its first appearance, it has spread over a wide section of the surrounding country and has caused the death of many thousands of vines and entailed a loss of many thousands of dollars. Mr. Pierce, as the special agent of the Department of Agriculture, had spent two years in studying the subject when the present report was sub. mitted, in June, 1891, and since then has continued his investigations. The report is an exhaustive one in many respects, an unsatisfactory one in others. For example, while he has given a very full account of the rise and progress of the vine industry in California and Mexico, and has examined with great care the bearings of soil conditions and of meteorological phenomena on the disease, the remedy for the evil, or even suggestions for palliation of it, are meagre in the extreme. It might be said, it is true, that as the origin and cause of the disease is still unknown, it is not possible to prescribe a remedy. Everything that has so far been tried bas given negative results. Numerous facts have been brought out by the investigation. Among them may be noted that drainage, irrigation, soil characters, rainfall, and temperature have had no effect in causing the disease. But that shade has in some unknown manner the effect of retarding the progress of the malady. It has also been ascertained that the disease is not caused by certain species of fungi or by certain animal or insect parasites, and that it differs in several ways quite markedly from Chlorosis and Pouritiore as these occur in Europe. The colored plates that are given illustrate very well the effects of the disease on the leaves and canes.

The second of the titles above given is an account of experiments conducted in the vicinity of Washington and in New York State for the prevention of plant diseases. These experiments bear out the previous work of the department. They show that, in the treatment of black rot of the grape, Bordeaux mixture still takes the lead; and that half strength, i. e, 3 pounds of copper sulphate, 2 pounds of fresh lime, and 22 gallons of water, gives as good practical results as full strength. In the treatment of apple scab, Bordeaux mixture was also very effective, but not so much so as Paris green. This is a new fact inasmuch as this substance, while known to be effective against insects, has not been generally supposed to be a fungicide. There was a higher percentage of first quality fruits and a less percentage of third quality as well as wormy fruits when this substance was used than any other. The experiments in New York were largely negative, since the amount of disease present was comparatively slight. The subjects treated were various kinds of nursery stock, and here again Bordeaux mixture gave as a whole the best results. Two plates showing sprayed and unsprayed grapes bear testimony to the good effects of the treatment for black rot.

The third title, "Grasses of the Pacific Slope," consists of illustrations and descriptions of grasses growing in California. Oregon, Washington, and Alaska. Some of them are of value for forage, while others are of scientific interest only. This is Part I. of the second volume of "Iilustrations of North American Grasses," the first volume, also in two parts, haring treated of the grasses of the south-west. The reports cannot fail to be of great interest and value to all students of botany.

JOSEPH F. JAMES.

Comparative Architecture. By BARRE FerReE. The author, New York.

THIS is a reprint of a paper read before the American Institute of Architects at its twenty-fifth annual meeting, at Boston, in October, 1891. Il is handsomely printed in royal octavo, and covers fifteen pages in clear and pleasing type. In this discourse, the distinguished author applies to architecture the comparative method which has proved so fruitful in the study of language and of biology. "Comparative Architecture" takes " the facts of historical and descriptive architecture, and describes the comparative progress made by all nations, and under all conditions." 